\title{
Legemiddelmangel - årsaker og tiltak
}

\author{
Legemiddelmangel i Norge skyldes i stor grad forhold utenfor våre grenser og utenfor vår kontroll. Det er et \\ økende internasjonalt problem, og i fremtiden kan vi oppleve mer alvorlige mangelsituasjoner. Det er derfor \\ viktig å ha en effektiv organisering av legemiddelberedskapen.
}

Publisert først på nett 26.9. 2012

Legemiddelmangel synes å være et økende problem i mange land, også her i landet (1). Hva er årsakene, hvor alvorlig er situasjonen, og hva kan gjøres?

Det siste året har vi i Norge hatt flere tilfeller av legemiddelmangel som har skapt overskrifter i avisene (tab 1). Disse mangelsituasjonene er løst gjennom ulike tiltak, men har medført både rutineendringer i sykehus og bytte av legemiddel for store pasientgrupper. Digitoksin er nå avregistrert i Norge, og alle pasienter som skal fortsette med digitalis, må gå over til digoksin (2). I kjølvannet av dette byttet har vi dessverre fått meldinger om dødsfall som følge av digoksinoverdose. En epidemi av mycoplasmainfeksjon ved årsskiftet 2011/12 medførte en voldsom økning i salget av erytromycinpreparater og dermed mangel på norske pakninger (3).

\section{Årsaker til legemiddelmangel}

Det er mange årsaker til legemiddelmangel (tab 2). I 2011 la Legemiddelverket ut 69 meldinger om ulike former for legemiddelmangel eller betydningsfulle avregistreringer på sine nettsider. Dette er det høyeste antallet siden tjenesten ble etablert i 2005 (4).

Legemiddelprodusentene har plikt til å melde alle tilfeller av avbrudd i legemiddelforsyningen til Legemiddelverket, men dette gjelder bare for legemidler med markedsføringstillatelse i Norge. Meldingsordningen er hjemlet i legemiddellovgivningen i Europa og gjelder alle EØS-land. Legemiddelverket har derfor god oversikt over mangelsituasjoner som skyldes forhold hos legemiddelprodusentene, slik som produksjonsvansker eller avregistreringer. I tillegg kan mangel skyldes problemer med distribusjon av legemidler eller videresalg av legemidler. I Norge er det lave priser på originallegemidler, og videresalg til andre land, såkalt parallelleksport, forekommer. For legemidler som finnes i Helsedirektoratets beredskapslager, er det $\mathrm{i}$ avtalen med grossist innført begrensninger i adgangen til parallelleksport. I 2011 fikk Legemiddel-

\section{«Det er verken praktisk eller økonomisk mulig å ha legemiddellagre i Norge som kan dekke opp for legemiddel- mangel i alle tenkelige
situasjoner»}

verket en melding om legemiddelmangel som etter vår vurdering sannsynligvis skyldes parallelleksport. Den berørte legemiddelgrossisten har nå endret sine rutiner.

Vår erfaring er at de fleste tilfeller av legemiddelmangel skyldes produksjonsvansker eller avregistreringer, ikke problemer med legemiddeldistribusjonen i Norge. Norske grossister skal levere til apotekene innen 24 timer så lenge legemidlene er tilgjengelige. Tilsynsavdelingen ved Legemiddelverket følger med på at legemiddeldistribusjonen skjer i henhold til regelverket.

Legemiddelverket har et team bestående av farmasøyter og leger som har det daglige ansvaret for å følge opp meldingene fra legemiddelindustrien. Teamet skal i samarbeid med aktørene på legemiddelområdet prøver å finne løsninger på problemene. Ved mer alvorlige situasjoner blir også Helsedirektoratet koblet inn, blant annet dersom det er spørsmål om å bruke legemidler fra beredskapslagrene (tab 3 ).

Internasjonalt er legemiddelmangel et betydelig problem (5). I USA har det vært store problemer med leveranser av blant annet viktige onkologiske legemidler. President Barack Obama har instruert Food and Drug Administration om å gjennomføre tiltak for å redusere forekomsten av legemiddelmangel (6). Tiltakene omfatter blant annet innføring av meldeplikt og nedkorting av tiden det tar for å godkjenne generiske legemidler.

\section{Legemiddelberedskapen}

Helsedirektoratet er nå i sluttfasen av en større gjennomgang av legemiddelberedskapen. Vi er på flere måter særlig utsatt dersom det skulle oppstå langvarig legemiddelmangel: Norge er et lite marked og har en minimal egenproduksjon av virkestoffer. De fleste legemidler som produseres her i landet, er basert på importert virkestoff/råstoff.

Det er verken praktisk eller økonomisk mulig å ha legemiddellagre i Norge som kan dekke opp for legemiddelmangel i alle tenkelige situasjoner. En viktig del av gjennomgangen av legemiddelberedskapen er derfor å identifisere legemidler det er kritisk viktig å ha tilgjengelig til enhver tid og som det bør finnes beredskapslagre av. Eksempler på kritiske legemidler er insulin til pasienter med type 1-diabetes og legemidler som hindrer avstøtning av transplan-

Tabell 1 Eksempler på legemiddelmangel i Norge i 2011-12

\begin{tabular}{|c|c|c|c|}
\hline Legemiddel & Legemiddelgruppe & Årsaker & Tiltak \\
\hline Tiopental & Bedøvelsesmiddel & $\begin{array}{l}\text { Produksjonsvansker } \\
\text { Eksportforbud pga. bruk ved henrettelser } \\
\text { i USA }\end{array}$ & $\begin{array}{l}\text { Rasjonering på sykehusene } \\
\text { Overgang til andre legemidler } \\
\text { Import av preparater uten markedsføringstillatelse }\end{array}$ \\
\hline Liposomalt doksorubicin & Cytostatikum & $\begin{array}{l}\text { Produksjonsvansker } \\
\text { Ikke godkjent myndighetsinspeksjon }\end{array}$ & Overgang til tilsvarende legemidler \\
\hline Digitoksin & Hjertemedisin & $\begin{array}{l}\text { Produksjonsvansker } \\
\text { Avregistrering }\end{array}$ & $\begin{array}{l}\text { Bruk av utenlandske pakninger } \\
\text { Overgang til digoksin }\end{array}$ \\
\hline Erytromycin & Antibiotikum & $\begin{array}{l}\text { Tredobling av etterspørselen som følge av } \\
\text { mycoplasmaepidemi }\end{array}$ & $\begin{array}{l}\text { Overgang til andre legemidler } \\
\text { Bruk av utenlandske pakninger }\end{array}$ \\
\hline
\end{tabular}


Tabell 2 Årsaker til legemiddelmangel

Legemiddelindustri

Sykdom

Regulatoriske tiltak fra myndighetene

Salg og distribusjon av legemidler
Råvaremangel

Avregistrering eller produksjonsstans

Uhell og ulykker

Ett eller få produksjonssteder

Små og sårbare generikaprodusenter

Oppkjøp, sammenslåinger, rasjonalisering

Ikke godkjent myndighetsinspeksjon

$\emptyset k t$ etterspørsel, f.eks. epidemier

Endrede behandlingsanbefalinger

Tilbaketrekkinger, f.eks. pga. bivirkninger eller kvalitetssvikt

Mindre lagre

Strammere logistikk

Nye markeder

Overflytting av salg

Redusert markedsadgang

Konkurranse

Tabell 3 Tiltak ved legemiddelmangel

Helsemyndighetene

Legemiddelgrossister

Legemiddelprodusent

Apotek

Leger og sykehus
Informasjon til leger, sykehus og apotek

Råd om alternativ behandling

Tillatelse til salg av utenlandske pakninger (uten søknad om spesielt godkjenningsfritak)

Tillatelse til salg av legemidler uten markedsføringstillatelse i Norge

Tillatelse til bytte eller substitusjon på apotek

Rasjonering av legemidler etter avtale med legemiddelfirma eller grossist

Refusjon for utenlandske pakninger

Refusjon for legemidler uten markedsføringstillatelse i Norge

Bruk av beredskapslagre

Finne leverandører og alternative legemidler

Ha oversikt over lagersituasjonen i Norge

Ha oversikt over forbruk og behov

Varsle helsemyndighetene

$\emptyset$ ke produksjonen

Løse produksjonsproblemer

Kvalitetssikring, etterleve myndighetspålegg

Informere pasienter

Stå for bytte eller substitusjon

Henvise pasienter til lege for alternativ behandling

Velge annen behandling, avvente behandling

Rasjonere legemiddel (sykehus)

Forbeholde legemiddel til pasienter med stort behov når alternativ behandling ikke finnes terte organer. Uten disse legemidlene vil pasientene være i en livsfarlig situasjon i løpet av få dager.

Legemiddelprodusentene er ofte ansvarlige for legemiddelmangelen, samtidig som de også sitter med løsningen på mange av problemene. Et godt samarbeid mellom legemiddelprodusentene og myndighetene er nødvendig for at pasienter ikke skal bli skadelidende. Legemiddelmangel oppstår i noen tilfeller uventet, andre ganger er det tydelig at det vil oppstå mangel i fremtiden. Da er tidlig varsling til myndighetene og helsetjenesten svært viktig, slik at det blir tid til å finne gode løsninger.

\section{Steinar Madsen}

steinar.madsen@legemiddelverket.no

Ulrika Claesson

Gro Ramsten Wesenberg

Statens legemiddelverk

\section{Marit Endresen}

Anne-Berit Walter

Helsedirektoratet
Steinar Madsen (f. 1956) er spesialist i indremedisin og hjertesykdommer. Han er medisinsk fagdirektør ved Statens legemiddelverk og arbeider i deltidsstilling som privatpraktiserende spesialist.

Forfatter har fylt ut ICMJE-skjemaet og oppgir ingen interessekonflikter.

Ulrika Claesson (f. 1979) er cand.pharm. og forsker ved Statens legemiddelverk.

Forfatter har fylt ut ICMJE-skjemaet og oppgir ingen interessekonflikter.

Gro Ramsten Wesenberg (f. 1947) er dr.odont. og direkt $\varnothing r$ i Statens legemiddelverk.

Forfatter har fylt ut ICMJE-skjemaet og oppgir ingen interessekonflikter.

Marit Endresen (f. 1961) er bioingeniør og har hovedfag i fysiologi og en dr.philos.-grad fra Det medisinske fakultet ved Universitetet i Oslo. Hun er avdelingsdirektør i Helsedirektoratet. Forfatter har fylt ut ICMJE-skjemaet og oppgir ingen interessekonflikter.
Anne Berit Walter (f. 1960) er master i farmasi og seniorrådgiver i Helsedirektoratet. Forfatter har fylt ut ICMJE-skjemaet og oppgir ingen interessekonflikter.

\section{Litteratur}

1. Apeland SG Manglande tryggleik i medisinforsyninga. Tidsskr Nor Legeforen 2012; 132: 1062

2. Statens legemiddelverk. Overgang fra digitoksin til digoksin hos voksne. www.legemiddelverket.no/ templates/InterPage_83376.aspx (20.5.2012)

3. Blystad H, Anestad G, Vestrheim DF et al. Increased incidence of Mycoplasma pneumoniae infection in Norway 2011. Euro Surveill 2012; 17. pii: 20074.

4. Statens legemiddelverk. Legemiddelmangel og avregistreringer. www.legemiddelverket no/ templates/InterPage 32564.aspx?filterBy= CopyToMedecs (20.5.2012).

5. Ventola CL. The drug shortage crisis in the United States: causes, impact, and management strategies. P T 2011: 36: 740-57.

6. Chabner BA. Drug shortages - a critical challenge for the generic-drug market. N Engl J Med 2011; 365: $2147-9$

Mottatt 1.6. 2012, første revisjon innsendt 23.8. 2012, godkjent 12.9. 2012. Medisinsk redaktør Petter Gjersvik. 